\title{
Spectrophotometric Simultaneous Determination of Benazepril and Hydrochlorothiazide in Commercial Pharmaceutical by Chemometric Methods
}

\author{
A. Hakan Aktas (Corresponding author) \\ Suleyman Demirel University, Science and Art Faculty \\ Department of Chemistry, Isparta, Turkey \\ E-mail: hakanaktas@sdu.edu.tr \\ Tugce Pekuz \\ Suleyman Demirel University, Graduate School of Natural and Applied Sciences \\ Department of Chemistry, Isparta, Turkey \\ E-mail: Tugce_Pekuz@hotmail.com
}

The research is financed by Suleyman Demirel University Scientific Project FYL-2018-6903

\begin{abstract}
In this study, models were developed for the simultaneous determination of Benazepril (BEN) and hydrochlorothiazide (HCT) in drug samples using chemometric approaches using UV spectrophotometry. It was used to calculate the calibration mixes between 200 and $360 \mathrm{~nm}$ wavelengths at $5 \mathrm{~nm}$ intervals for the spectra of BEN and $\mathrm{HCT}$ at various concentrations. The least squares calibration method and principal component regression were used for chemometric analysis of the data and the parameters of the chemometric procedures were optimized. The analytical performances of this chemometric method were compared by characterizing the sum of the residual errors' squares (PRESS), estimated standard error (SEP) and recoveries (\%). A series of synthetic mixtures containing different concentrations of BEN and HCT were studied to control the predictive ability of the chemometric methods applied. This method was successfully applied to real samples, it was not affected by excipients as stated in the recovery study results. The results obtained in this review encourage these chemometric methods to apply these strategies for standard research and quality control of two active ingredients.
\end{abstract}

Keywords: Benazepril, Hydrochlorothiazide, Partial Least Squares Calibration, Principal Component Regression.

DOI: $10.7176 / \mathrm{JSTR} / 6-04-04$

\section{Ticari İlaç Tabletlerinde Benazepril ve Hidroklorotiazidin Eşzamanlı Kemometrik Yöntemlerle Belirlenmesi}

\begin{abstract}
Özet
$\mathrm{Bu}$ çalışmada, UV spektrofotometrisi kullanılarak kemometrik yaklaşımlarla ilaç örneklerinde Benazepril (BEN) ve hidroklorotiazid (HCT) in eş zamanlı olarak belirlenmesi için modeller geliştirilmiştir. Çeşitli konsantrasyonlarda BEN ve HCT' nin spektrumları için 200 ve 360 nm dalga boyları arasındaki kalibrasyon karışımlarını $5 \mathrm{~nm}$ aralıklarla hesaplamak için kullanıldı. Verilerin kemometrik analizleri için en küçük kareler kalibrasyon yöntemi ve temel bileşen regresyonu kullanıldı ve kemometrik prosedürlerin parametreleri optimize edildi. Bu kemometrik yöntemin analitik performansları artıkların hatalarının toplamının kareleri (PRESS), tahmini standart hata (SEP) ve geri kazanımlar (\%) ile karakterize edilerek karşılaştırılmaları yapıldı. Uygulanan kemometrik yöntemlerin tahmin yeteneğini kontrol etmek için farklı konsantrasyonlarda BEN ve HCT içeren bir dizi sentetik karışımla çalışıldı. Bu yöntem gerçek numunelere başarılı bir şekilde uygulandı, geri kazanım çalışması
\end{abstract}


sonuçlarında belirtildiği gibi yardımcı maddelerden etkilenmedi. Bu incelemede elde edilen sonuçlar, bu kemometrik yöntemleri iki etken maddenin standart araştırması ve kalite kontrolü için bu stratejileri uygulamaya teşvik etmektedir.

Anahtar Kelimeler: Benazepril, Hidroklorotiazid, En Küçük Kareler Kalibrasyonu, Temel Bileşen Analizi

\section{Introduction}

Multivariate calibration methods have historically been an important field of application for chemometrics as it has been applied to analytical chemistry. An important part of the applied chemometric methods includes multivariate calibration. Some groups have based most of their development over the last two decades mainly on partial least squares (PLS) algorithm and principal component regression (PCR) applications. PLS and PCR are generally considered to be the main regression techniques for multivariate data. As a result of the application of such methods to combined drug analyzes, fast, simple, cheap and reproducible results are obtained.

The modern spectroscopic instruments used today are so fast that they can produce hundreds of spectra in a matter of minutes for a particular sample containing multiple components. In contrast, the univariate calibration methods require an interference-free system and are rather slow, as they are not suitable for such data. Since multivariate calibration is related to data containing device responses measured at multiple wavelengths for a sample containing more than one component, it is especially preferred in drug analysis today.

The popular advances in chemometrics and computers in recent years have led to the development of several variable calibration methods (Haaland et al, 1988; Wentzell et al, 1997) for the analysis of complex chemical mixtures such as drug formulations.

The combination of benazepril and hydrochlorothiazide is one of the drugs used to treat high blood pressure. It is known that the combination benazepril is from a class of drugs called angiotensin converting enzyme (ACE) inhibitors. This active substance tries to reduce some chemicals that tighten the blood vessels, making the blood flow more smoothly in the body.

Benazepril is a converting enzyme inhibitor, also known as angiotensin, used to treat hypertension. Hydrochlorothiazide is also a diuretic widely used thiazide. Hypertension is treated with the combination of these two active ingredients. In the presence of excipients in the examples, without any separation, the mixture, containing two or more compounds, determining the solubility of the systems at the same time is one of the important issues of the pharmaceutical industry and its analytical chemistry. The literature survey reveals that several methods were reported for the individual estimation of BEN and HCT. The simultaneous quantitative determination of both drugs at the same time in pharmaceutical tablets using various methods including spectrophotometry (Dinç, 2002; El-Gindy et al, 2001; Erk, 1999; Panderi, 1999; Durmuş et al, 2005; Parmar et al, 2013), HPLC (Banoğlu et al, 2000; Panderi et al, 1999; Manna et al, 2001), and capillary electrophoresis (Hillaert et al, 2001) have been described for many mixtures. Working two forms of active ingredient are shown in Figure 1.

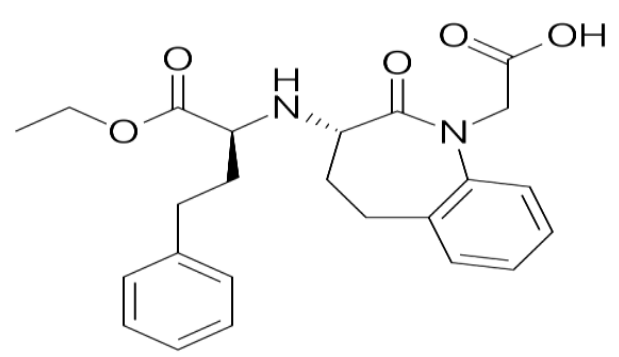

a)

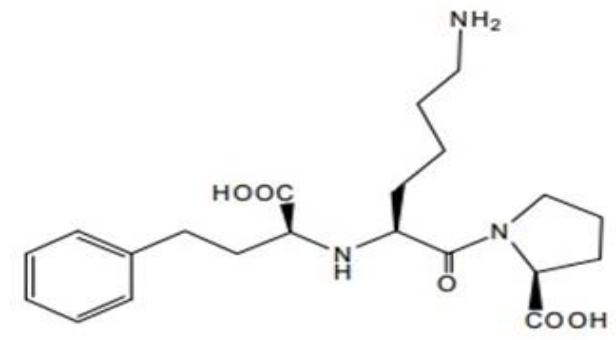

b)

Figure 1. Structure of the drugs a) BEN b) HCT

The multivariate calibration techniques use full spectrum, full automation, multivariate data analysis and the reduction of noise and the advantages of the selection calibration model. In addition, these multivariate calibrations do not need any separation procedure, they are very cheap, very easy to apply and very sensitive. For these reasons these multivariate techniques are popular today. 
In this study, two powerful chemometric methods were applied to analyze synthetic mixtures and tablets consisting of BEN and HCT in the presence of interactions of absorption spectra. The application of chemometrics is vital to the success of identifying clinical drugs at the same time as it allows interpretation of multivariate data.

\section{Experimental Section}

\subsection{Apparatus}

A Shimadzu (Model UV-1700) UV-Visible spectrometer (Shimadzu, Kyoto, Japan), equipped with $1 \mathrm{~cm}$ matched quartz cells was used for spectrometric measurements.

\subsection{Standard solutions}

Analytical grade materials were used in experiments. Stock solutions of $100 \mathrm{mg} / 100 \mathrm{~mL}$ BEN and HCT were prepared in $0.1 \mathrm{M} \mathrm{NaOH}$. The solutions were stable for the least a week if they had been stored in a cool $\left(<25^{\circ} \mathrm{C}\right)$ and dark place.

2.3. Pharmaceutical preparations A commercial drug preparations; Cibadrex $®$ tablet produced by Meda Pharma, Turkey, containing $10 \mathrm{mg}$ benazepril and $12.5 \mathrm{mg}$ hydrochlorothiazide per tablet, was analyzed by the proposed chemometric techniques.

\subsection{Procedure for dosage form}

A precisely weighed pummeled tablets comparable to $100 \mathrm{mg}$ of the considered medications was separated with $10 \mathrm{~mL}$ of $0.1 \mathrm{M} \mathrm{NaOH}$, weakened with water, and sonicated for around $30 \mathrm{~min}$. The concentrates were separated into $100 \mathrm{~mL}$ volumetric carafes at that point washed and weakened to volume with refined water. Aliquots these arrangements were moved into a progression of $10 \mathrm{~mL}$ volumetric jars and the examination were finished as spectrometric method. Every one of the systems were connected to the last arrangement.

\subsection{Chemometric methods}

PLS and PCR is a factor research technique with a two-phase method in mind, an adjustment attempts in which a scientific model is studied using part foci and ghostly information from a reference arrangement followed by a prediction attempt in which the model is used to determine the indeterminate sample detected from its range. These techniques are similarly called factor strategies because they transform the first factors into less symmetric factors called Elements or basic segments (PCs), which are straight mixtures of the first factors. At the point where multivariate tuning approaches are connected in spectrophotometric multi-segment examination, a link is created between the resulting and fixing information from the reference tests by referring to the factors of the framework. New factors have been created by PCs and another grid created by scores. The calculation of this new Lattice is regulated by computation open to the embraced relapsing technique.

The real distinction in the current capacities of these two strategies is that it predicts that PLS is superior to PCR when there are freely different major ghost segments covering random direct baselines or imaginary highlights of the review. The ideal of tuning technique is based on specific test conditions. Regardless, the PLS seems to have reached a sensible decision on a wide range of circumstances.

\section{Results and Discussion}

Figure 2 shows the absorption spectra for BEN and HCT and their mixture in $0.1 \mathrm{M} \mathrm{NaOH}$.

In order to build the chemometric calibration, a training set was randomly prepared by using the standard mixture solution containing $4.0-12.0 \mu \mathrm{g} / \mathrm{mL}$ BEN and $5.0-15.0 \mu \mathrm{g} / \mathrm{mL}$ HCT in the variable proportions as shown in Figure 3. The absorbance data matrix was obtained by measuring at the 14 wavelengths with the intervals $\Delta \lambda=5 \mathrm{~nm}$ in the $225-290 \mathrm{~nm}$ spectral region. The prepared calibrations of two techniques using the absorbance data sets were used to predict concentration of the unknown values of BEN and HCT in their mixture. 


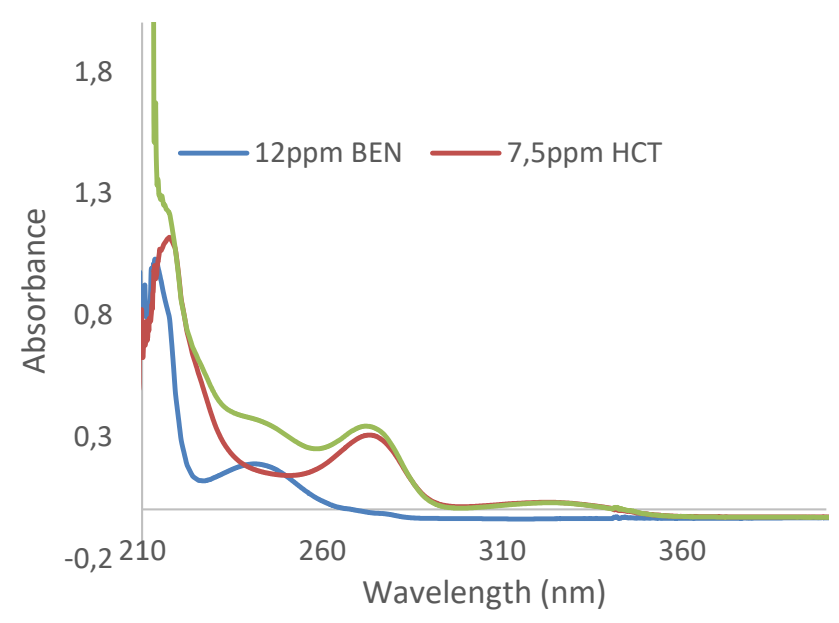

Figure2. Original absorption spectra of $12.0 \mathrm{ppm} \mathrm{BEN,} 7.5 \mathrm{ppm} \mathrm{HCT}$ and their mixture in $0.1 \mathrm{M} \mathrm{NaOH}$

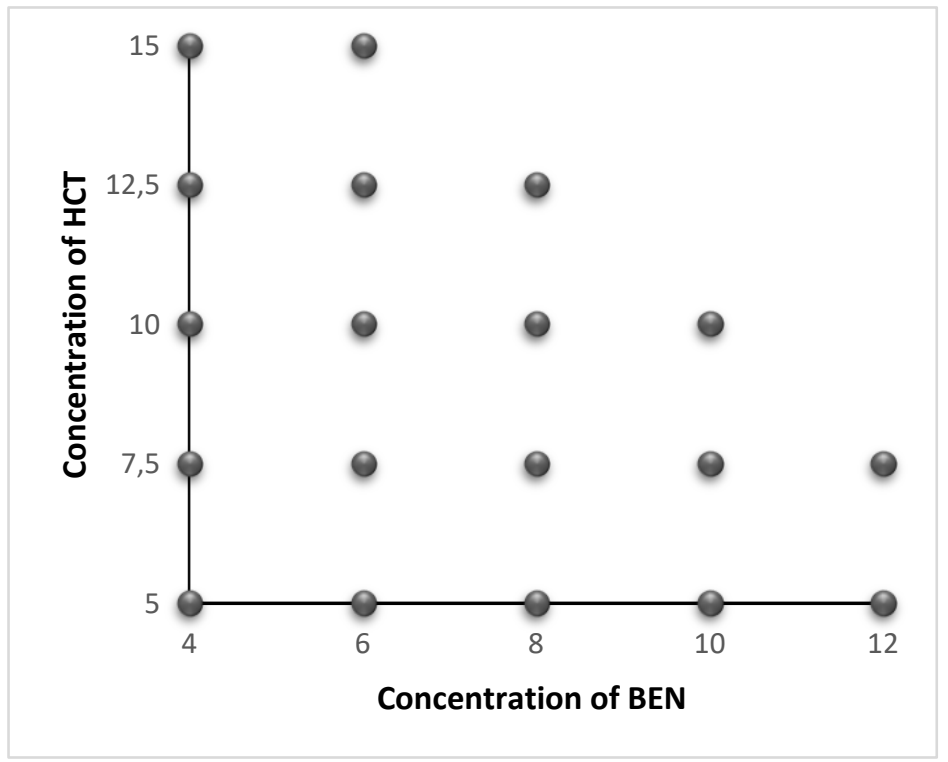

Figure 3. Concentration set design for the preparation of PLS and PCR calibration

A calibration for each technique was computed in the MINITAB 16.0 and PLS Toolbox 4.0 software by using set consisting of two drugs and their absorbance data. The multivariate calibrations of two techniques were used to predict the unknown concentrations of BEN and HCT in the samples.

The application adequacy of a calibration model can be explained in several ways. Validation of the calibrations configured for the training set and synthetic binary mixtures of both drugs can be verified by statistical parameters. These results can also be examined numerically. One of the best ways to do this is by reviewing the estimated residual error frames total or PRESS. To calculate PRESS, it calculates errors between expected and predicted values for all samples, squares and is combined.

$$
\text { PRESS }=\sum_{i=1}^{n}\left(C_{i}^{\text {added }}-C_{i}^{\text {found }}\right)^{2}
$$

Strikingly speaking, this is not a correct way to normalize the PRESS values when not all of the data sets contain the same number of samples. If we want correctly compare PRESS values for data sets that contain differing numbers of samples, we should convert to standard error of prediction (SEP), which is given by following formula. 


$$
\mathrm{SEP}=\sqrt{\frac{\sum_{i=1}^{n}\left(C_{i}^{\text {added }}-C_{i}^{\text {found }}\right)^{2}}{n-1}}
$$

Where $C_{i}^{\text {added }}$ the added concentration of drug is, $C_{i}^{\text {found }}$ is the found concentration of drug and $\mathrm{n}$ is the total number of the synthetic mixtures. The SEP can provide a good measure of how well, on average, the calibration model performs. Often, however, the performance of the calibration model varies depending on the analyte level. In the application of two chemometric techniques to the synthetic mixtures containing two drugs in variable compositions, the mean recoveries and relative standard deviations for PLS and PCR were found to be $100.5887 \%, 7.0507 ; 99.9830 \%, 0.6374$ and $97.0226 \%$, $4.5357 ; 100.0103 \%, 0.0148$ respectively for BEN and for HCT (Table 1).

Table 1. Recovery values for the applied chemometric methods

\begin{tabular}{|c|c|c|c|c|c|}
\hline \multicolumn{2}{|c|}{ Mixture $(\mu \mathrm{g} / \mathrm{mL})$} & \multicolumn{2}{|c|}{ Recovery (\%) } & \multirow[b]{3}{*}{ BEN } & \multirow[b]{3}{*}{ HCT } \\
\hline & \multirow{2}{*}{$\frac{\text { PL }}{\text { HCT }}$} & \multicolumn{2}{|c|}{ PCR } & & \\
\hline BEN & & BEN & HCT & & \\
\hline 4.00 & 5.00 & 107.7438 & 100.3598 & 98.6230 & 100.0110 \\
\hline 6.00 & 7.50 & 98.8478 & 99.5837 & 98.4364 & 100.0221 \\
\hline 8.00 & 10.00 & 99.7863 & 100.4029 & 98.5252 & 100.0248 \\
\hline 10.00 & 12.50 & 101.9437 & 100.0997 & 98.2866 & 100.0253 \\
\hline 12.00 & 15.00 & 96.8978 & 99.7545 & 97.4523 & 100.0273 \\
\hline 2.00 & 5.00 & 93.1985 & 100.6807 & 94.3434 & 100.0057 \\
\hline 2.00 & 7.50 & 106.2926 & 99.8125 & 91.8943 & 100.0149 \\
\hline 2.00 & 10.00 & 110.9755 & 99.9019 & 89.3564 & 100.0169 \\
\hline 2.00 & 12.50 & 111.3877 & 100.1187 & 86.3564 & $\overline{100.0206}$ \\
\hline 2.00 & 15.00 & 92.7246 & 98.6509 & 100.5730 & 100.0221 \\
\hline 4.00 & 2.50 & 87.0547 & 100.0943 & 100.5890 & 99.9792 \\
\hline 6.00 & 2.50 & 99.9049 & 100.0352 & 100.8421 & 99.9971 \\
\hline 8.00 & 2.50 & 104.5777 & 101.4444 & 100.7996 & 99.9906 \\
\hline 10.00 & 2.50 & 93.9606 & 99.3469 & 98.4246 & 99.9929 \\
\hline 12.00 & 2.50 & 103.5334 & 99.4587 & 100.9540 & 100.0033 \\
\hline & Mean & 100.5887 & 99.9830 & 97.0226 & 100.0103 \\
\hline & RSD* & 7.0507 & 0.6374 & 4.5357 & 0.0148 \\
\hline
\end{tabular}

RSD*: Relative Standard Deviation

According to the added concentration and the concentration found in samples, the PRESS and SEP values of PLS and PCR techniques were calculated $1.3797 ; 0.2800$ and $0.0115 ; 5.8255 .10^{-5}, 0.3032 ; 0.1366$ and 0.0277; 0.0019 respectively for BEN and HCT (Table 2).

Table 2. Statistical parameters in the calibration-prediction for PLS and PCR methods

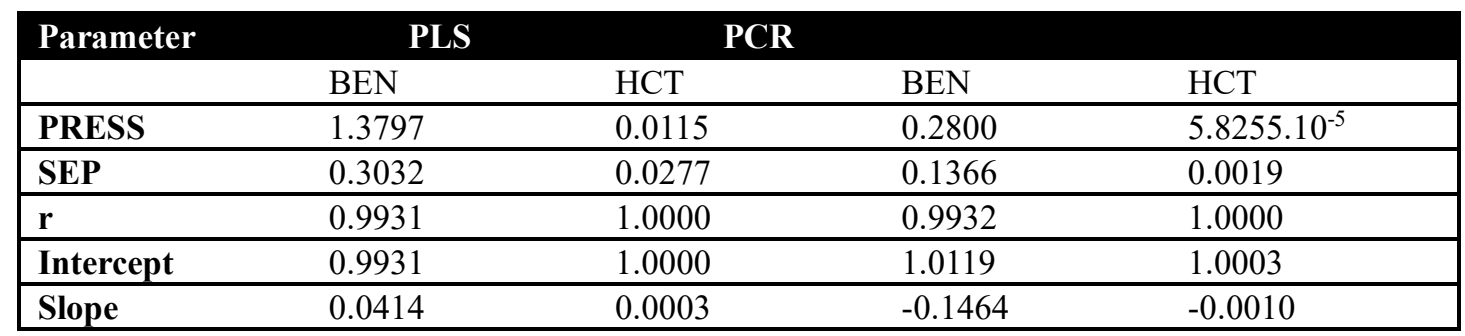


The linear regression analysis of the added concentration and the concentration found in the synthetic mixtures were realized for each drug and for each calibration techniques. In this regression analysis, the correlation coefficient (r), intercept, slope and relative standard deviation values were found satisfactory for the proposed chemometric techniques in Table 2 . As can be seen, all the statistic values indicated that all techniques are convenient for the determination of two active components in synthetic mixtures.

Accuracy and precision for the analysis of BEN and HCT substances in the prepared synthetic mixtures at three different concentration levels $(4.00,8.00$ and $12.00 \mu \mathrm{g} / \mathrm{mL}$ for BEN and 5.00, 10.00 and 15.00 $\mu \mathrm{g} / \mathrm{mL}$ for HCT) in intra-day $(n=6)$ and inter-day $(n=6)$, was tested for the applicability of the proposed chemometric methods. The calculated results for percent relative error, standard deviation and relative standard deviation were presented in table 3 and 4 . Good accuracy and precision were observed for the results obtained by PLS and PCR calibrations.

Table3. Accuracy and precision results for PLS

\begin{tabular}{|c|c|c|c|c|c|c|c|c|c|c|c|}
\hline \\
\hline Added & $(\mu \mathrm{g} / \mathrm{ml})$ & \multicolumn{5}{|c|}{ BEN } & \multicolumn{5}{|c|}{ HCT } \\
\hline BEN & $\mathrm{HCT}$ & Found & SD & $\%$ BSS & $\% \mathrm{RE}$ & $\begin{array}{l}\text { Recovery } \\
(\%)\end{array}$ & Found & SD & $\%$ BSS & $\% \mathrm{RE}$ & $\begin{array}{l}\text { Recovery } \\
(\%)\end{array}$ \\
\hline 4.00 & 5.00 & 4.0021 & 0.0243 & 0.6075 & 0.0509 & 100.0510 & 5.0025 & 0.0304 & 0.6074 & 0.0509 & 100.0510 \\
\hline 8.00 & 10.00 & 7.9967 & 0.0156 & 0.1955 & -0.0418 & 99.9581 & 9.9958 & 0.0195 & 0.1954 & $\overline{-} .0419$ & 99.9582 \\
\hline 12.00 & 12.00 & 12.0013 & 0.0199 & 0.1661 & 0.0109 & 100.0109 & 15.0016 & 0.0249 & 0.1662 & 0.0109 & 100.0210 \\
\hline & & & & & $\overline{\mathbf{x}}$ & 100.0067 & & & & $\overline{\mathbf{x}}$ & 100.0101 \\
\hline & & & & & SD & 0.0465 & & & & SD & 0.0466 \\
\hline & & & & & BSS & 0.0005 & & & & BSS & 0.0004 \\
\hline & & & & & LOD & 0.1537 & & & & LOD & 0.1636 \\
\hline & & & & & LOQ & 0.4655 & & & & LOQ & 0.4656 \\
\hline
\end{tabular}

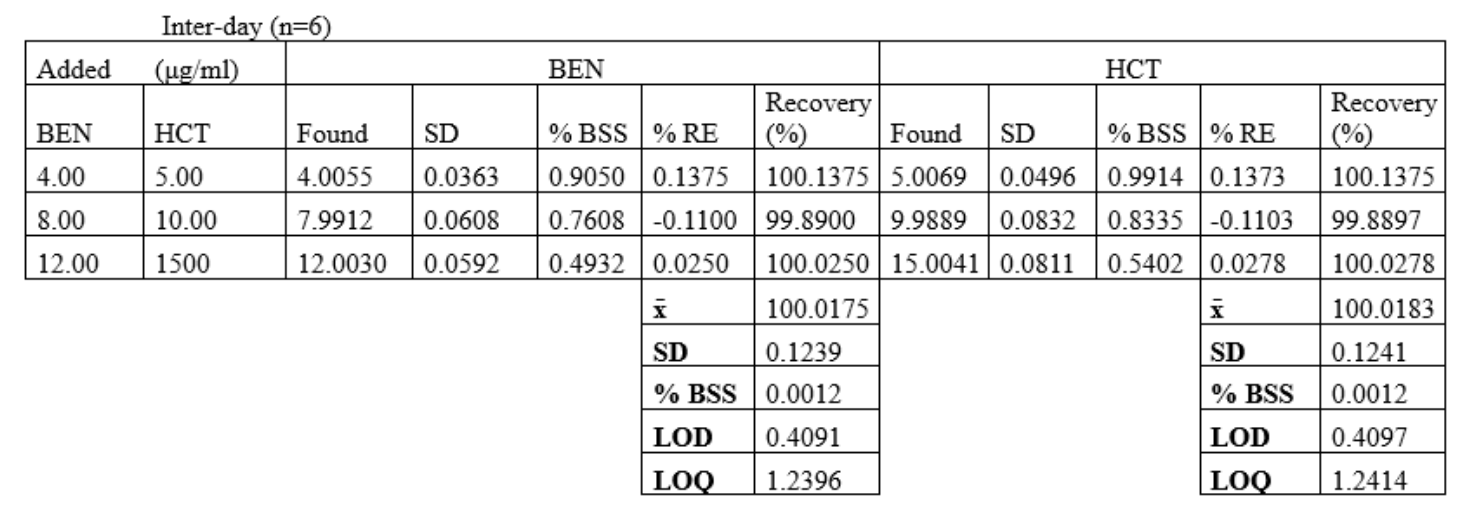


Table4. Accuracy and precision results for PCR

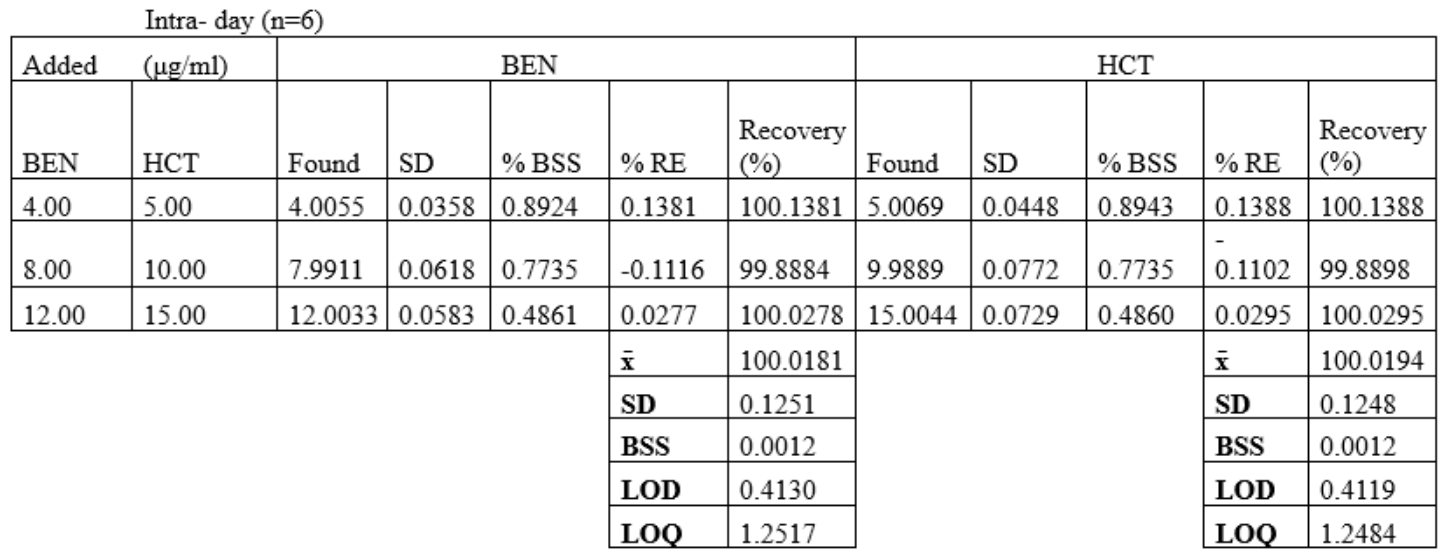

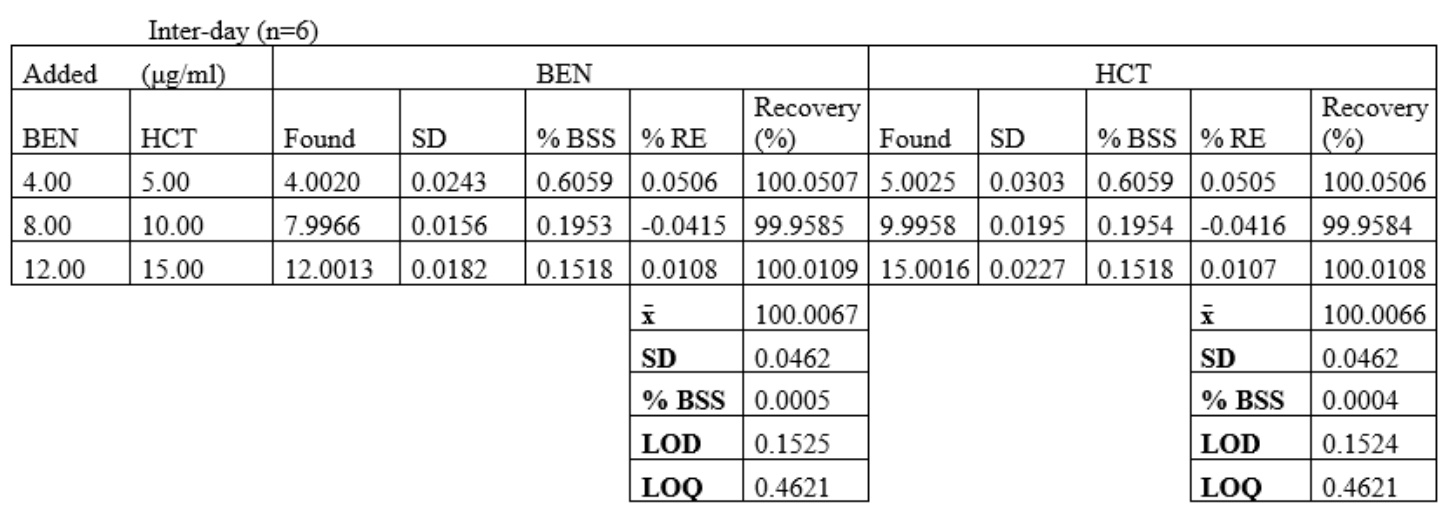

A summary of the assay results for the pharmaceutical formulation is given Table5. The results of all methods were very to each other as well as to the label value of commercial drug formulation.

Table 5. Assay results for the pharmaceutical formulation (mg/tablet)

\begin{tabular}{|lc|} 
Drug & PCR \\
\hline BEN & \\
Mean \pm SD* & $9.99 \pm 0.08$ \\
HCT & $12.50 \pm 0.04$ \\
Mean \pm SD* & \\
& \\
\hline
\end{tabular}

Results obtained are average of six experiments for each technique.

*SD : Standard deviation

\section{Conclusion}

PLS and PCR, which are powerful chemometric methods in spectrophotometric examination, have been proposed for the simultaneous assurance of BEN and HCT in binary mixtures. These strategies were successfully achieved on a commercial drug tablet. Exceptionally, the targets of covering drug mixtures have been achieved by using PLS and PCR methods. Determination of the working wavelength with 
high correlation values with fixation due to impedance or extra analytes arising from the frame test. As can be seen with the results obtained, it was seen that PLS and PCR chemometric methods gave more precise results in this drug mixture. The proposed chemometric methods were found to be able to bind two drugs in the tablet definition for normal examination without the previous connection section and without being boring.

\section{Acknowledgement}

This research work has been supported by research grants from Süleyman Demirel University Scientific Research Project FYL-2018-6903.

\section{References}

Dinç E., (2002). Spectral analysis of benazepril hydrochloride and hydrochlorothiazide in pharmaceutical formulations in tablets by chemometric analysis methods. Il Farmaco, 58:1032-1039.

El-Gindy, A., Ashour, A., Abdel-Fattah, L., Shabana, M.M., (2002). Spectrophotometric determination of benazepril hydrochloride and hydrochlorothiazide in binary mixture using second derivative, second derivative of the ratio spectra and chemometric methods. J. Pharm. Biomed. Anal., 25: 299-307.

Erk, N., (1999). Determination of active ingredients in the pharmaceutical formulations containing benazepril hydrochloride, triamterene and cilazapril by ratio spectra derivative spectrophotometry and vierordt's method. J. Pharm. Biomed. Anal., 20: 155-167.

Banoğlu, E., Özkan, Y., Atay, O., (2000). Dissolution tests of benazepril-HCl and hydrochlorothiazide in commercial tablets: Comparison of spectroscopic and high-performance liquid chromatography methods. Il Farmaco, 55:477-483.

Panderi, I.E., Parissi-Poulou, M., (1999). Simultaneous determination of benazepril hydrochloride and hydrochlorothiazide by micro-bore liquid chromatography. J. Pharm. Biomed. Anal., 21:1017-1024.

Hillaert, S., Van Der Bossche, W., (2001). The quantitative determination of several inhibitors of the angiotensin-converting enzyme by CE. J. Pharm. Biomed. Anal., 25: 775-783.

Haaland, D.M., Thomas, E.V., (1988). Partial least squares methods for spectral analysis. 1. Relation to other quantitative calibration methods and the extraction of qualitative information. Anal. Chem., 60:1193-1202.

Wentzel, P.D., Andrews, D.T., Kowalski, B.R. (1997). Maximum likelihood multivariate calibration. Anal. Chem., 69:2299-2311.

Parmar, V., Chhalotiya, U., Shah, D., Bhatt, K., Baldania, S., (2013). Quantification of benazepril hydrochloride and hydrochlorothiazide in tablet dosage forms by simultaneous equation spectrophotometric method. Journal of Applied Chemistry, 1-5.

Durmuş, Ö., Dinç E., (2005). Determination of benazepril hydrochloride and hydrochlorothiazide in pharmaceutical preparations using UV-Visible spectrophotometry and genetic multivariate calibration methods. J. of Food and Drug Anal., 13: 301-311.

Manna, L., Valvo, L., Alimonti, S., (2001). A liquid chromatographic ion-pairing method for simultaneous determination of benazepril hydrochloride, fosinopril sodium, ramipril and hydrochlorothiazide in pharmaceutical formulations. J. of Chromatographia, 53:271-275. 